\title{
Towards sustainable cities and communities: Is psychological preparedness include in the disaster risk reduction policy framework in Indonesia
}

\author{
Listyati Setyo Palupi ${ }^{1 * 2345}$ \\ ${ }^{1}$ Psychology Department, Universitas Airlangga, Jl. Airlangga 4-6, Surabaya, East Java, Indonesia \\ ${ }^{2}$ Addiction Study Centre, Jl. Airlangga 4-6, Surabaya, East Java, Indonesia \\ ${ }^{3}$ Health and Environmental Sustainability (HES) Research Group, J1. Airlangga 4-6, Surabaya, East Java, Indonesia \\ ${ }^{4}$ Technology and Psychology of Social Change Research Group, Jl. Airlangga 4-6, Surabaya, East Java, Indonesia \\ ${ }^{5}$ Direktorat Riset dan Pengabdian Masyarakat (DRPM) RISTEKDIKTI Indonesia Penelitian Dasar (PD) research funding scheme \\ 2021 (No. 528/UN3.15/PT/2021)
}

\begin{abstract}
Indonesia geographical location that surrounded by Australia plate, Pacific plate, and Eurasia plate has made the country exposed to disasters. Natural hazard that often happen in Indonesia are flood, volcanic eruption, earthquake, landslide, land fire, cyclone, extreme wave. The impact of disaster was devastating economically, socially and psychologically for affected community as well for the whole nation. Indonesia National Disaster Management Authority (NDMA) has noted that average losses caused by disaster is 30 trillion rupiah per year. Studies found that preparing individual to face disaster could help to reduce the impact of the disaster. However, the effort is still not enough and yet Indonesia is still suffering a great loss due to disasters. The disaster preparedness program that was available was mostly focused in technically prepare people and neglect the importance of psychologically prepare people to face disaster. The purpose of the study is to analyse current disaster risk reduction policy framework in Indonesia, examine whether the current policy framework has address and includes psychological preparedness for disaster and propose a solution for designing appropriate policy to reduce psychological impact of disaster.
\end{abstract}

\section{Introduction}

Indonesia geographical location that surrounded by Australia plate, Pacific plate, and Eurasia plate has made the country exposed to disasters. Natural hazard that often happen in Indonesia are flood, volcanic eruption, earthquake, landslide, land fire, cyclone, extreme wave. It has been noted that during 10 year period from 20102020, natural disaster has caused 1.183 people died in Indonesia [1]. Indonesia National Disaster Management Authority (NDMA) has noted that average losses caused by disaster is 30 trillion rupiah per year [2]. Disasters has a devastated impact for Indonesian people not only in terms of economically but also socially and psychologically. Effort has been placed and policy has been implemented to reduce the risk and impact of disaster in order to reach one of the Sustainable Development Goals in achieving sustainable cities and communities.

One of priority for action in disaster risk reduction that are applied by Government Indonesia is improving disaster preparedness to respond effectively to a disaster. However, the effort is still not enough and yet Indonesia is still suffering a great loss due to disasters. The disaster preparedness program that was available was mostly focused in technically prepare people and neglect the importance of psychologically prepare people to face disaster [3]. According to Tanesab [4], regulatory system and policy practices of disaster risk management should be strengthened and synchronized in order to increase the effectiveness of disaster risk reduction in Indonesia [4]. Thus, it is important to analyze the disaster risk reduction policy that has been implemented in Indonesia in order to reduce the risk of disaster and achieve sustainable cities and communities as state in the Sustainable Development Goals. Policy analysis has been done to examine the disaster policy implemented in Indonesia. However, most of the study is mostly focus on insurance or tax policy that concern with post disaster financing to reduce the risk of loss caused by natural disaster [5,6]. Most research is focused more on management, legislative processes and risk reduction programs. There are five main aspects of the disaster management system that require renewal, namely institutional aspects, budgetary aspects, disaster management implementation aspects, policy aspects, and disaster types aspects [7].

The purpose of the study is to analyze current disaster risk reduction policy framework in Indonesia, examine whether the current policy framework has address and includes psychological preparedness for disaster and propose a solution for designing appropriate policy to reduce psychological impact of disaster. This

*Corresponding author: listyati.palupi@psikologi.unair.ac.id 
paper presents an overview covering (1) Risk of Disaster in Indonesia (2) factors that influences disaster in Indonesia, and (3) current disaster risk reduction policy framework in Indonesia. In conclusion, a series of suggestions to address issues related to mangrove policy framework in Indonesia are offered.

\section{Method}

This research used document analysis method which is a systematic procedure for reviewing or evaluating documents - both printed and electronic (computerbased and Internet-transmitted) material $[8,9]$. The analytic procedure entails finding, selecting, appraising (making sense of), and synthesizing data contained in documents. Document analysis yields data-excerpts, quotations, or entire passages - that are then organized into major themes, categories, and case examples [8]. Content analysis was used to analyze the contents of the policies and legislations related to disaster risk reduction in Indonesia. Indonesian legal system nowadays has seven layer or hierarchy which are basic constitution, general people assembly decree, Laws and Acts, government Regulations substitute law or Act, government regulations, presidential decrees, and regional government regulations. However, this research only focuses on Acts in the central government level. Source of data that used in this research is policies documents.

\section{Results}

\subsection{Risk of disaster in Indonesia}

Indonesia is recognized as natural disaster-prone country due to its location that are surrounded by three big tectonic plate which are Australia plate, pacific plate, and Eurasia plate [3]. The Indonesia National Disaster Management Agency has recorded 11,274 disasters happen in 4 years periods from 2015 until 2019 [10].

Several province that affected by disaster during this period are Aceh, North Sumatra, West Sumatra, Riau, Jambi, South Sumatera, Bengkulu, Lampung, Bangka Belitung, DKI Jakarta, West Java, Central Java, Yogyakarta, East Java, Banten, Bali, Java, Sulawesi, West Nusa Tenggara, East Nusa Tenggara, West Kalimantan, South Kalimantan, East Kalimantan, North Kalimantan, North Sulawesi, Central Sulawesi, South Sulawesi, West Sulawesi, Gorontalo, Maluku, North Maluku, West Papua, and Papua [11]. Natural disaster that happens in Indonesia the last year are earthquake, volcano eruption, landslide, flood, drought, extreme weather, tidal wave, forest and land fire and plague [11].

\subsubsection{Earthquake}

The National Disaster Management Agency has mapped the area that are prone to earthquake. Indonesia island that are indicated as earthquake prone areas are Sumatra, Java, Bali, Nusa Tenggara, Maluku, Sulawesi and Papua [10].

\subsubsection{Tsunami}

Tsunami is generated from deformation of seabed caused by an earthquake which trigger huge sea waves when it happens in the sea. Tsunami will have a tremendous effect especially for the coastline area. Indonesia is an archipelagic country with 13.700 island that have the second largest coastline in the world [12]. Thus, most of Indonesia region becomes prone to tsunami disaster.

\subsubsection{Volcanic eruption}

Indonesia is in the third rank of country with the most volcanoes in the world [13]. It is recorded that there are 129 active volcanoes from 500 volcanoes that exist in Indonesia. The region that are identified prone to volcanic eruption are Sumatera, Java, Lombok, Bali, Sumbawa, Flores, Banda Sea, Sulawesi, Sangir island, Halmahera [10].

\subsubsection{Avalanche}

Landslide could be cause by volcanic eruption or earthquake. Since Indonesia has 139 volcanoes therefore the country has regions that are exposed to landslide. The National Disaster Management Agency has identified the Indonesia regions that are avalancheprone area West Java, Central Java, and East Java [14].

\subsubsection{Flood}

Flood is also one of the disasters that happen frequently in Indonesia. Indonesia has two seasons, i.e. the hot season and rainy seasons that could potentially create hydro-meteorological hazards such as flooding and drought. Aceh, North Sumatera, Riau, Jambi, South Sumatera, Bengkulu, Lampung, Bangka Belitung, West Java, Central Java, East Java, Yogyakarta, Banten, West Nusa Tenggara, West Kalimantan, Central Kalimantan, South Kalimantan, East Kalimantan, Central Sulawessi, West Sulawesi, Northwest Sulawesi, North Maluku, West Papua, Papua is considered to have a high risk of flood disaster [15].

\subsubsection{Drought}

Drought is another hydrometeorological hazards that often impacts Indonesia. Several districts/cities in Indonesia that are identified as drought zone are West Sumatra, Riau, Jambi, South Sumatra, Bengkulu, Lampung, Bangka Belitung Islands, Riau Islands, nearly all districts/cities in Java Island, except for those situated in the easternmost part of Java Island, and several districts/cities in East Nusa Tenggara Province, West Kalimantan, Central Kalimantan, South Kalimantan, East Kalimantan, North Sulawesi, South Sulawesi, West Sulawesi, North Maluku and Papua [10].

\subsubsection{Forest and land fire}

Indonesia is position at the top 8 of countries with the widest forest area [16]. Forest fire is one of natural 
hazard that often strike Indonesia regions several regions that are in high risk of forest and land fires include Sumatra islands, Kalimantan Islands, Sulawesi islands, East Nusa Tenggara islands, and Java Island [17].

\subsection{Factors that influence disaster in Indonesia}

Natural hazard is often happened in Indonesia. There are several factors that influence the magnitude impact of disaster toward Indonesian society. Society vulnerability to natural hazard could be grouped into physical, social, and economical vulnerability [18]. The distance of a community to the source of hazard, poorly planned development, poor quality infrastructure, ground factors, building physical conditions are factors that influence the society vulnerability toward disaster $[10,19]$. Social and economic vulnerability that influence the community susceptibility to disaster is socioeconomic status, marital status, place of residence, age head of household, built environment [20].

\subsection{Current disaster risk reduction policy framework in Indonesia}

There are 2 parliamentary laws, 4 Presidential Decree, 3 government regulations, 1 ministerial decree and 102 regulations that relate to disaster risk reduction activities in Indonesia. However, this study is only focus in analyzing 2 parliamentary laws that become the basis in all of disaster risk reduction effort and activities which are Act No. 24 of 2007 and Act No. 26 of 2007.

\subsubsection{Law of the Republic of Indonesia number 24 of 2007}

Act Number 24 of 2007 is the central law that regulate the disaster management activities which consists of 13 Chapters and 80 Articles. The main material outline the principles and aims of disaster management, inter organization role in disaster management which include responsibility and authority of the government and regional government, the role of National Disaster Management of Indonesia at the state and regional level, the right and obligation of the society, disaster management scope, disaster management stage and the description of action in each of the stage; financial source of disaster management activities, and the role of international organizations in disaster management implementation.

Law No 24 of 2007 state that the central government is authorized to declare the status and level of disaster by considering the number of people impacted, the infrastructure damage, loss of property, facilities damage, the coverage of the disaster, and social and economic impact of disaster [21]. Study found that psychological preparedness for disaster could influence the magnitude of disaster impact for the community [22-24]. Beside of that, psychological preparedness for disaster also correlated with resilience [25]. Therefore, psychological preparedness for disaster could become one of indicators that could be use to determine the status and level of disaster. However, study found that although psychological preparedness for disaster has been acknowledged as an important factor in disaster management that could influence the magnitude of disaster impact for the community nevertheless psychological preparedness for disaster is remain unnoticed [3]. It is also true that psychological preparedness for disaster is still forsaken in the Law No 24 of 2007. Therefore, disaster preparedness of the community should be included as one of measured indicator to declare the status and level of disaster. Hence, disaster preparedness should be state in Chapter 3 Article 7 Paragraph 1 and 2.

The role and authority of government and supporting agency also stated in of the Act No 24 of 2007. The National Disaster Management Agency according to Chapter 3 article 12 is assigned to manage the disaster management activities which includes providing guideline and direction on disaster prevention, emergency responses, rehabilitation, and reconstruction phase [21]. Although it has mention disaster prevention as part of the disaster management however disaster preparedness is not yet account. Study found that psychologically preparing the community to face disaster will have a significant influence in reducing the mental heath risk of being exposed to disaster. Therefore, considering the importance of psychological preparedness for disaster, the disaster preparedness especially psychological preparedness for disaster should also be assign as the National Disaster Management Agency task that state in Chapter 3 Article 12 paragraph 1 of Law No 24 of 2007. Furthermore, psychological preparedness for disaster should also inserted into disaster management planning that stated in Chapter 3 Article 36 Paragraph 4 of Law No 24 of 2007. In addition, the psychological preparedness for disaster could also be included as part of alertness that could be clearly describe in Article 45 Paragraph 2, Article 45 Paragraph 2 and Article 47 Paragraph 2 of Law No 24 of 2007.

\subsubsection{Law of the Republic of Indonesia number 26 of 2007}

The Law on Disaster Management Number 26 of 2007 is law that stipulate the spatial planning regulation in Indonesia. The Act consist of 80 articles divided into XIII Chapters. The main point stressed in the Act are the spatial planning principles, spatial planning classification, the role and responsibility of the authority in spatial planning, establishment of spatial planning, spatial management, supervision in spatial planning, the right and role of the community.

Spatial management regulation is an effort to promulgate the legal basis for the Government, local government and society in spatial management. The Act regulate the spatial planning in Indonesia and state that the spatial management should follow several principles which are integrity, compatibility, harmony and balance, sustainability, productivity and profitability, openness, togetherness and partnership, protection of public interest, legality and justice, and accountability.

The Law No 26 of 2007 has taken into account disasters factors in planning the spatial structure and 
pattern. Disasters has stated as part of Law No 26 of 2007 and mention in Article No 6 Paragraph 1 about Spatial Planning Classification, Article 20 Paragraph 5 about national spatial plan, Article 23 Paragraph 5 about provincial spatial plan, Article 26 Paragraph 6 about regency spatial plan, and Article 28 Paragraph 1 about municipal spatial planning [26]. This is shown that disasters are account in the process of designing a spatial plan for rural area, agripolitan area, urban area, metropolitan area, megapolitan area. However, disaster is not specified in the spatial management establishment, execution, and supervision.

Considering the devastating impact of disaster. Therefore, disaster should also include in Chapter 3 article 4 of Law No 26 of 2007 as one of the factors that used to classify spatial management. Furthermore, disaster should also be use to determine the content of spatial planning including the space structure and space pattern especially in province, regency, and municipal planning which is state in Chapter IV article 7 of Law No 26 of 2007. Beside including in Chapter III and IV of Law no 26 of 2007, disaster should also be include in execution of spatial management that stated in Chapter VI Section 1 Section 2, section 3, section 4, and section 5 .

\section{Conclusions}

Based on the analysis of current Indonesia government legal framework that associated with disaster management, there are several recommendations that could be implemented to improve the effectiveness of disaster risk effort by specifically describe the focus of disaster risk reduction effort to not only focus in reducing the risk in general but also to include psychological preparedness as an integrated part in the disaster management planning.

Based on the analysis of potential disaster that might strike Indonesia as a result of geographical location and also the document analysis of Government Law that govern disaster management, this article formulated several key recommendations to strengthen the Indonesia's legal framework for Disaster Management as mean to reduce the risk of disaster for the nation, as well as addressing some of the major gaps especially in related to psychological preparedness for disaster. The following are the recommendations:

1. Amendments of Disaster Management Law which are Law No 24 of 2007 by including disaster preparedness especially psychological preparedness for disaster in the Chapter and Article specifies below:
a. Chapter III Article 7 paragraph 1 and 2,
b. Chapter III article 12 paragraph 1 ,
c. Chapter III Article 36 Paragraph 4, No 24 of 2007,
d. Chapter VII Article 45 Paragraph 2, Article 45 Paragraph 2 and Article 47 Paragraph 2.

2. Amendments Law No 26 of 2007 that govern spatial management planning to support the Law No 24 of 2007 by integrating disaster factor and propose the following amendments:

a. Chapter III article 4,
b. Chapter IV article 7,
c. Chapter VI Section 1,
d. Chapter VI Section 2,
e. Chapter VI section 3,
f. Chapter VI section 4,
g. Chapter VI section 5

\section{References}

1. D. B. Raharjo and S. Aranditio, 1 (2021)

2. R. Dwinanda, 1 (2021)

3. L. S. Palupi, in Sustain. Islands Dev. Initiat. - Int. Conf. 2019 (IOP Conference Series: Earth and Environmental Science, 2021), pp. 1-9

4. J. P. Tanesab, Int. J. Disaster Manag. 3, 1 (2020)

5. Kalfin, S. S. Sukono, M. Mustofa, and A. T. Bon, 1825 (2020)

6. D. Dubelmar, M. Astrin, D. Kartini, and S. Mareli, 5, 243 (2020)

7. T. A. Syadzily, 1 (2020)

8. G. A. Bowen, Qual. Res. J. 9, 27 (2009)

9. S. L. Dalglish, H. Khalid, and S. A. McMahon, Health Policy Plan. 35, 1424 (2020)

10. S. Maarif, National Disaster Management Plan (Rencana Nasional Penanggulangan Bencana 2015-2019) (2014)

11. BNPB, (2021)

12. Oishimaya Sen Nag, WorldAtlas 1 (2020)

13. Horsemart, 1 (2015)

14. felicia F. Facette, 1 (2018)

15. Badan Nasional Penanggulangan Bencana (BNPB), Indeks Risiko Bencana Indonesia (IRBI) Tahun 2020 (Badan Nasional Penanggulangan Bencana (BNPB), 2020)

16. Worldometer, 285 (2019)

17. S. P. Nugroho, Badan Nas. Penanggulangan Bencana 5 (2017)

18. National Agency for Disaster Management of Indonesia, Indonesia National Disaster Management Plan 2010-2014 (Jakarta, 2010)

19. G. Yüce, G and Arun, in 15 WCEE (Lisboa, 2012)

20. M. Llorente-Marrón, M. Díaz-Fernández, P. Méndez-Rodríguez, and R. G. Arias, Sustain. 12, 1 (2020)

21. Republic of Indonesia, Law of The Republic of Indonesia Act No 24 of 2007 (Indonesia, 2007), pp. 588-595

22. S. A. Morrissey and J. P. Reser, Aust. J. Emerg. Manag. 18, 46 (2003)

23. J. Roudini, H. R. Khankeh, and E. Witruk, Heal. Psychol. Open 4, 1 (2017)

24. J. Roudini, H. R. Khankeh, E. Witruk, A. Ebadi, K. Reschke, and M. Stück, Heal. Emergencies Disasters Q. 2, 165 (2017)

25. L. S. Palupi and M. Noor Rahman Himawan, in E3S Web Conf., edited by B. W. Sudarno and T. . Putranto (E3S Web Conference, 2020), pp. 0-5

26. Republic of Indonesia, Law of The Republic of Indonesia Act No 26 Year 2007 (Indonesia, 2007), pp. 1-95 